\title{
The Influence of Flipped Learning Methods on High School Learners' Biology Attainment and Social Intelligence in Kuwait
}

\author{
Ali Hassan Ebrahim ${ }^{1 *}$, Salwa A Ben Naji ${ }^{2}$ \\ ${ }^{1}$ Curriculum \& Instruction, College of Education - Kuwait University, KUWAIT \\ ${ }^{2}$ College of Education English Unit Kuwait University, KUWAIT
}

Received 2 July 2020 • Accepted 15 June 2021

\begin{abstract}
The present study aims to discuss the influence of the flipped learning method (FLM)—on high school biology learners to improve the results of their biology attainment tests along with their use of social interactions while learning. By applying quasi-experimental study, 37 female high school biology learners in 2 intact grade 10 classes in Kuwait were selected as the study objects. A class was randomly chosen as the experimental group and another class as the control group. The students in the experimental group applied flipped learning strategy while the control group applied the traditional direct method. The teaching experiment for both classes lasted for 5 weeks (10 sessions). Using an attainment test administered by the teacher as a pretest and a post-test, the attainment of the biology students was measured. The researchers also conducted a survey to examine their social intelligence and it was given along with the pretest and the post-test. The breakdown of the attainment test results showed that flipped learning methods actually have ( $p$ $<.05)$ more positive influence on the students' attainment than the direct methods. The learners under the flipped teaching methods outperformed the learners under the direct methods on their attainment learning. However, as for the results of their social intelligence, the ANCOVA test revealed a non-significant difference between the two classes whether they were under the influence of flipped learning methods or the direct teaching methods due to some reasons mentioned later in this paper. Still, flipped learning method effect on the student' learning attainment led to positive results and would lead other teachers to implement FLM in Kuwaiti classrooms. The researchers also suggest that the College of Education at Kuwait University train pre-service teachers to apply modern teaching strategies, such as FLM.

This paper presents an important topic. It summaries primary literature concerning flipped classrooms compared to direct teaching methods, discusses limitations of both methods, clarifies benefits of flipped learning methods, and offers recommendations for teachers to implement flipped learning methods.
\end{abstract}

Keywords: biology attainment, flipped learning methods, high school biology, social intelligence, teacher-directed methods

\section{BACKGROUND AND INTRODUCTION}

Since the 1960s, scientific subjects have been essential subjects taught in schools around the world particularly in developing countries in order to close the gap between the advanced world and the developing countries in terms of technology and medicine. Hence, Kuwait has focused on incorporating scientific subjects such as biology and some other scientific subjects into the school curriculums and the Ministry of Education is supervising it closely (Ebrahim, 2012). However, lately some educators in Kuwait have thought that they should change their traditional methods in teaching scientific subjects such as biology as we need to promote the way students think, stimulate their critical thinking and sharpen their mental ability in biology by using modern techniques. 


\section{Contribution to the literature}

- The given technical experiments of the investigation present practical ways for measuring the influence of flipped learning on students' biology attainment and social intelligence practice.

- The findings indicate that the use of FLM show positive outcomes on students.

- Performing FLM in Kuwaiti educational systems can possibly lead to a good rehabilitation in the scientific fields and it might lead to changing the outdated academic methods such as the traditional methods.

- The study achieved an effective flipped teaching by having learners watch informative teaching films that would allow them to answer questions of the lesson before even the course starts.

- Exchanging teaching films among teachers could possibly reduce the time of lesson preparation especially for new hired teachers.

- This study made us believe that learners would be able to learn and retain information better through flipped learning methods than the traditional ones.

- By conducting this experiment we reached the conclusion that by switching the duties of the teacher from being a content giver at the class stage into a receiver of students comments and responses of real situations prepared prior to class time, the class co-operation became much more successful and beneficial.

Kuwaiti leaders know that learning is an essential means for achieving goals and an important element for developing countries in today's changing world. However, since 1911, education in Kuwait has been greatly centralized by the Ministry of Education that has direct control over its schools (Ebrahim, 2012). Certain teaching methods were designed to be applied in all of its schools. For all of the subjects and biology among them, actually, traditional (i.e., direct teaching) methods were mostly followed. These methods chiefly favored giving live lectures and employed activities that need repetitions and memorization as the primary way of conveying information to learners.

In fact, today, in biology classes most lecturers in Kuwait still use the familiar traditional approach for teaching. Some teachers and followers of the direct teaching method still think that, in order to get to advanced levels of learning, educators have to coordinate thought-provoking exercises and comprehensible lessons that are smooth and easy to follow according to learners' needs and capacities. However, in recent years, several studies have pointed out that learners learn by performing instead of merely listening to teachers who fully occupy the learners' attention throughout the learning process. Actually, teachers can embrace technology and take advantage of the various tools to benefit their students (Saglam \& Arslan, 2018). However, some teachers and biology teachers among them still believe that learners' achievement is anticipated and manageable when using traditional teaching methods more than any other method (Al-Kandari, 2006). But some of today's Kuwaiti educators, on the contrary, choose to apply individualized and student-directed strategies because such strategies allow learners to produce and work on tasks without getting face-to face help from their teacher. Instead, they watch teaching films and cooperate with other students to seek academic success with great confidence. Many Kuwaiti teachers aim to advance students' scientific perception and keep them up to date with the most current scientific and technological advancements. They assume that the traditional lecture that follow direct teaching method-and-recitation processes, has somehow substantial theoretical and practical foundation in science classrooms. They also assume that direct teaching pedagogy strongly emphasizes intensifying the time consumed in the lecture. Moreover, large number of educators assume that learners' analytical thinking, comprehending, and scientific literacy are not as much important as the grades they achieve from the tests. Al-Kandari (2006) stated that more than $90 \%$ of the targets noted in science lecturers' notebooks in Kuwait included a memorization of instructions. However, according to Trends in International Mathematics and Science Study (TIMSS) 2015 test results in science and mathematics for grade eight, Kuwait ranked $33^{\text {rd }}$ out of 39 countries, indicating that schools' outcomes are neither dependable nor alluring (Martin et al., 2016).

To adjust the Kuwaiti education in science especially biology as it is a key subject for medicine colleges, the educators have recognized the value of promoting knowledge acquisition. Kadioglu, Uzuntiryaki, and Capa-Aydin (2011) in fact, noted that efforts to promote knowledge acquisition should not only include the enhancement of content information, but also the strengthening of study skills, social interactions, and desired stimulating orientations in order to help learners become more self-reliant and lifelong learners. Therefore, adjustments in Kuwaiti education have already now become more obvious in a limited number of learning communities that started to employ new methodologies of instruction. To summarize, the main goal in education today has become to build up 
instructions that promote higher levels of accomplishment and develop the usage of social intelligence at the same time. Yet, it is crucial to assess these methodologies of teaching and provide lecturers with strong foundation that enable them to choose and use varied effective methods.

In fact, the effectiveness of different types of instructional methods on students' academic attainment have been assessed by many recent studies. Based on previous information, this research aims to explore the influence of utilizing flipped learning methods compared to direct teaching methods in the biology classrooms of tenth grade in Kuwait to improve their attainment in biology and develop their social intelligence.

Direct teaching as mentioned earlier in the background was the most traditional and common teaching method used mostly in Kuwait. Under this type of teaching environment, learners usually lack prior thinking of lesson's content, so learners accept information as it comes from the teacher without any input from the learner's side. Besides, the teacher deals with his/her students as if all of them think evenly with no differences in their talents or abilities. However, the problem starts when they reach home and start to do homework with no success. Unfortunately, they have no one to assist them. Therefore, a gap is created here between absorbing the information in class and applying it at home. As a result, flipped learning method came to improve the direct teaching method and address these challenges. The concept behind it is to flip the receiver of information into a giver and vice versa. Almutairi et al. (2020), stated that flipped learning is supported by constructivist learning theory and considered to be a change in the use of in-and out-of-class time. It provides chances for informal and outdoor education settings (Tomas et al., 2019). The learners would come to class and would have already grasped concepts of the lesson from the teaching video clips that should be given earlier by the teacher and students would go through the lesson's questions before even class starts. Learners would also learn from online teaching practices that would meet their individual levels and rates of comprehension. Their attitudes in class group work would change from passive listeners to active and interactive. Teachers as well would be more able to monitor the learners' performance and would provide adaptive and instant feedback (Fulton, 2012: Herreid \& Schiller, 2013; Hughes, 2012).

\section{RESEARCH FOCUS}

This study is after enhancing Kuwaiti high school biology learners' attainment in biology by using flipped learning that support cooperative learning. (Kong, 2014) stated that flipped learning could promote learner's learning attainment and offer more team cooperation.
Learners have been given informative teaching films or videos recorded by the teacher before class time. They were also able to use some web teaching pages. The teaching experiment took 5 weeks, about 10 sessions and it took place to understand more about the effects of flipped teaching methods on biology learners' attainment and their social intelligence.

This study leads to find out new methods to develop and update teaching methods. It is after teaching methods that focus on the role of the learner and make him/her the center of the learning process. Unlike traditional teaching which focuses on one way of instructions from the teacher's part and under such circumstances learners usually lack thinking of the lesson content critically (Li, Zheng, \& Yang, 2017). Finally, we can say that the study problem can be identified by answering the following questions: What is the influence of using the method of flipped learning on the academic attainment of tenth grade learners in the biology subject in our public schools in Kuwait? And does the flipped learning method make them more skillful in their social intelligence when studying together this subject?

\section{The Study Objectives and Importance}

This study aimed at identifying the influence of using the flipped classroom method on the learners' academic attainment and their social intelligence among tenth grade learners in the biology subject in public schools in Kuwait. The importance of this study derives from many important points. First, the possibility to make good use of the results and recommendations in developing and applying the flipped classroom methods in classrooms in Kuwait public schools. Second, this study might guide teachers to develop curricula of biology subject as well as contribute to the Arabic educational literature that belongs to flipped classroom topics and enrich its resources.

\section{LITERATURE REVIEW}

\section{Flipped Learning Methods (FLM)}

Why are the researchers after flipped learning methods? That's because flipped learning methods have become increasingly popular components of the learning and teaching processes in the classrooms today. Using this new methodology and modality, teachers want to spot new pedagogical strategies to attract students' attention (Sargent \& Casey, 2019). With this kind of method, the roles of students change from a passive listener to a positive interactive participant (Shi-Chun, Ze-Tian, \& Yi, 2014).

To identify flipped learning, we may say that flipped learning means that what is performed at home as traditional training is performed during classroom time and vice versa-namely, what is performed as 
traditional learning during classroom time is now done at home. Strayer (2012) explained more and said that teachers should make students get familiar with the course content beyond the learning settings so that learners would have enough time to be busy with the new material looking at it as something familiar in the actual learning zone (p. 171). Moreover, the content knowledge which is submitted to the students prior to the classroom meeting time should be given by using technological means to save time and effort. The content knowledge should be designed and beautifully constructed by the teacher to demonstrate a specific content-related topic throughout the lecture (Wiginton, 2013). Bishop and Verleger (2013) described flipped classrooms just as a pattern of stylish modern teaching methods that brilliantly apply up-to-date techniques to match the demands of today's learners.

It is worth mentioning as well that the concept behind flipped classrooms stems from constructivist theory where knowledge is constructed not transmitted. Constructionism and social constructivism assume that learning takes place when students are actively engaged in their own process of learning through social interaction (Li, Zheng, \& Yang, 2017). However, several researches went against this theory and noted that teaching/learning still successfully today continues to take place by using traditional ways particularly recently because of the advanced information age. Yet, the researchers think that there is still a need to develop learners' critical thinking skills and to stimulate positive happy learning experiences by using technology (Almodaires et al., 2018) stated. He also said that this adherence to traditional practices occurs because some teachers are unable to keep up with the advanced technologies.

In addition, constructionism is a theory that recognizes that learners' understanding, and knowledge can come from the learners' own experiences prior to having lectures and entering school. Thus, flipped learning permits and motivates learners to learn through self-learning activities given before the class time and ultimately let them have deep discussions inside the classroom (Li, Zheng, \& Yang, 2017). Therefore, flipped learning techniques have produced a shuffle in the educational industry shifting from completive-based instruction to collaborative-based instruction to address diversity in the classrooms (Bergmann \& Sams, 2012).

Kong (2014) also discovered that flipped teaching could enormously promote students' information literacy and their critical thinking ability. Plus, teachers and learners would have more time for information sharing and discussion before and after class. Several studies indicated that flipped learning would enhance the learning outcome and promote the development of various abilities. It is an interactive pedagogical model in which information takes place outside of class time. Class time is used for interactions and conceptual development (Cronhjort, Filipsson, \& Weurlander, 2017; Kwon \& Woo, 2018).

Flipped learning method has actually received considerable attention in Kuwait recently, but very little known about its effect on the learner's knowledge attainment and their social intelligence in biology subject for tenth grade in Kuwait. Local studies that investigate such area is rare and that makes it necessary to conduct this research study and what makes our study unique is that it is the first study to be done on biology learners with flipped learning methods for high school learners in Kuwait, and it is important that educators of Kuwait know about this study.

Implementing flipped learning methods offer magnificent chances for learners to be liable to analyze all the materials given before class meetings. Educators arrange lessons by using videos or multimedia that students could watch at home or anywhere else using laptops or smart phones before they meet in their lecture classrooms, while class time is reserved for other activities, practices, and classwork (DeLozier \& Rhodes, 2017). The flipped classroom concept also draws our attention to the procedures of flipping teaching and learning the powerful nature of using new technology gadgets when arranging and giving lectures. Thus, the instructor who needs to implement the flipped method must prepare subject matters and explain fresh data using stylish audio and visual video clips and virtual evaluations and make them available for students before even the beginning of the lesson. The educator's part following this method would be as a referee and a motivator of learners to encourage them to learn using subject matters before class time. Therefore, a flipped learning environment raises student-directed instruction and accelerates learning and comprehending in the learning zone (Asiksoy \& Ozdamli, 2016).

According to Asiksoy and Ozdamli (2016), the flipped method is a kind of learner-centered method. However, it allows learners to vigorously get the materials and the information for new lessons at a convenient time merely by making cell- phones or laptops or electrical appliances and IPads handy. These technological gadgets allow students to replay informative videos as many times as they need, to help them understand the new information and take any necessary notes. In addition, students can speed up the academic videos to ignore the parts they have already grasped. Implementing a flipped learning strategy would generate a promising result on learning in general. For example, students' individual differences can be considered, their performance can get better, their boredom can vanish, and their excitement for learning can increase (Esperanza, Fabian, \& Toto, 2016).

In flipped learning method, learners need the teacher to be around them in the classroom only to cover the materials that they came across previously by their own 
and couldn't understand. In addition, they do not want the teacher to speak about a topic that takes a long time or give a boring content. Instead, they can joyfully access content on their own (Bergman \& Sams, 2012). Bergman and Sams (2012) are arguing that in the flipped learning technique, learners learn by informative videos or other reliable functional resources outside the learning zone at their own convenient time and perform tasks and do interchanged activities in the classroom. Mok (2014) asserted that, in flipped learning zones, the educator gives lectures before class meeting time in the form of pre-recorded videos and he/she spends class time involving learners in learning tasks that involve cooperation, participating and socializing (p. 7).

Implementing flipped learning instructional methodology is achieved when learners study with informative recorded materials and online activities before class time and thus they can be engaged in interchanged and communicative debates that further simplify their understanding, application, analysis, evaluation, and creation during class time (Cheng, Ritzhaupt, \& Antonenko, 2018). In the flipped learning method, learners are on a tight firm timetable that has lectures in actual class meetings or normally in campus labs where they can have their projects done during the regular school time. They also have applicable and convenient work completed in online settings. Flipped learning stands for a combination of learning theories that once thought to be conflicting, problem-based learning activities that are founded upon a constructivist ideology and instructional lectures taken from direct instruction methods founded upon behaviourist principles (Bishop \& Verleger 2013, p. 1).

Active learning in the learning zones is as much essential as learning outside the learning zones (Cheng et al., 2018). Yet, the flipped learning methodology is not disregarding the real live lectures conducted inside learning zones. Actually, it converts only some parts of the lectures from being held in-class environment to be given outside the learning zone, such as the lecture's videos and the online activities.

\section{FLM Influence on Learners' Attainment}

Flipped learning is grounded on the notion of effectiveness especially when students actively expand their learning because they can have control over the time and place as they articulate their own understanding of the concepts. Therefore, the learning area becomes an interactive area where students collaboratively frame and outline information in a way that makes it comprehensive while having internal directions and thus, they become a source of the information itself (Garrison \& Vaughan, 2008). A lot of investigations have marked that the usage of the flipped learning method in the lecture room can enhance and develop students' performance. For example, Al-Rowais (2014) tested the influence of flipped learning on the learners' attainment and their social intelligence at the college of education. The sample was 64 learners who represented the sixth level in the College; they were randomly chosen. The author identified affirmative good impression upon achievements and attitudes towards learning. Elian and Hamaidi (2018) also studied the consequences of applying flipped learning methods on the intellectual attainment of 44 male and female fourth-grade students in Jordan. They were classified into two groups: experimental group and control group. The authors found statistically noticeable differences in the mean of the educational attainment test attributed to the teaching methodology, favoring the members of the experimental group. Strohmyer (2016) stated that the flipped learning method leads to the following benefits:

- Teachers can make good use of the classroom period, thereby guaranteeing enough time for guiding and helping students.

- Teachers can enhance students' critical thinking skills, self-study, curiosity, feeding back skills, socializing with other students, and motivation.

- Teachers can use technological techniques to assess students' understanding through tests and brief online assignments. Students performance can be checked, corrected and sent automatically by the software to the teacher. Then the teacher can read the indications of their results and quickly know their weaknesses and strengths of their content comprehension and understanding.

Rotellar and Cain (2016) summarized some of the rationales and results behind applying the flipped learning method in classrooms, such as increasing student engagement with content. They stated that the flipped learning method also increases and improves teachers' contact time with students and enhances learning. Millard (2012) identified five ways the flipped classroom works: it can increase students' engagement, strengthen team-based skills, offer personalized student guidance, focus particularly on the classroom discussion, and provide faculty with more free time.

Alzain (2015) concluded that the flipped learning style is a new and a convenient method in which we can use stylish technological gadgets as a solution for dealing with students' educational background deficiency while helping them develop skillful thinking. Alzain also suggested that the flipped learning methodology gives instructors enough time to review material issues with learners in the school room instead of relying on memorization. In addition, a flipped classroom can enhance learners' intellectual abilities. Using this method will help students increase their information in scientific, experimental, and behavioral aspects. Dickenson (2016) asserted that the flipped classroom is the active practice that enables students to connect what they learn to their private lives; they can 
also link what they learn to their intellectual behaviors until it becomes part of their personality.

\section{FLM Influence on Social Intelligence}

The psychology and sociology literature have recorded the influence of social intelligence on mental performances, knowledge acquisition, academic achievement, and future career achievements Students who conform to school rules develop enhanced learning outcomes because they acquire psychological intelligence, which is an essential source of school accomplishments (DiPrete \& Jennings, 2012). FLM are distinguished from other teaching approaches by providing a classroom environment focused on meaningful social skills (Al-Rowais, 2014). Many investigators have demonstrated the good impact of flipped learning method on learners like creating compassion between them, socializing, arousing selfesteem and motivation, which support their learning as these skills push them to more love and commitment. (Garrison \& Akyol, 2009; Noonoo, 2012).

\section{Criticisms of Flipped Learning Methods}

Tully (2014) identified some obstacles related to implementing a flipped classroom method, such as that this kind of teaching method which its main tool is the net and technological gadgets used at home, actually makes it hard for those learners without such gadgets to benefit from this approach. In addition, some researchers think that only a qualified motivated teacher is willing to follow up on students' progress and can be successful with it. Some educators think that flipped learning style demands giving more time and that educators should be skillful when including stylish upto-date technology into education. As for teachers who dislike gadgets or who hate to work closely with students, applying this method probably won't be easy.

Pashler et al. (2008) mentioned some issues that might affect negatively to the teaching processes when using digital appliances in the learning zones, including:

- The shortage of electrical gadgets used to record clips for the upcoming lessons.

- The limitations of instructors' abilities to operate skillfully gadgets which ultimately progress comprehending and communication among learners especially young ones.

- Teachers' determination to embrace traditional methods.

Still, compared to direct teaching methods, flipped learning is more reliable for elevating students' achievement once perfectly applied, yet it is true that not all the results of applying flipped learning would evenly be impressive. Various studies have included methodological shortcomings (Pashler et al., 2008); However, it is suggested that any difference or unlikeness found might be the outcome of misunderstanding the way in which the flipped learning should be done or sometimes some trainee teachers of flipped learning do not follow the instructions given by their supervisors properly. Hence, it is suggested that procedures, classroom content textbooks and processes within flipped learning should be patently expounded as well as clarified enormously especially for new teachers and inexperienced followers of flipped learning methods.

Researchers have proposed that instructors should regard flipped learning system as mutable, and comfortable and that changes in teaching approaches should be based on students' needs and their own interests. It is essential to learn the ground on which the effective flipped classroom is based (Alzain, 2015). For example, the perception of learning is focused on the student, who becomes the coordinator of the teaching and learning procedures. The instructor should identify the materials that learners will be acquiring outside the learning zone so that period time can be used to apply what students have prepared.

It is not easy to apply the flipped learning strategy effectively in regular traditional classrooms but Alzain (2015) pointed out to work productively you must have students feed-back and reflections from a working group that work inside classes and outside and this requires individual accountability in order to achieve the group ambitions. Then you would see learners busy working in direct interaction, showing good interdependence, and participating in recurrent practice using small-group interpersonal skills. Finally, flipped learning approaches normally cost more time and effort than direct teaching practices but it is worth it.

\section{Direct Teaching Method}

Direct teaching procedures stands for the traditional methodology of teaching that has long been used in most schools. In direct teaching, the teacher uses behavioral learning theory to create a learning environment. Instructional lectures derived from direct instruction methods were founded upon behaviorist principles (Bishop \& Verleger, 2013). This learning theory states that behaviors are learned from the environment and says that inherited factors have very little influence on behavior. A common example of behaviorism is positive reinforcement. For example, a student gets a small treat if they get high grades on their biology test. In the future students work hard and study for their test in order to get the reward. Additionally, traditional approaches followers presume that knowledge only comes from the instructor in the learning zone; accordingly, learners should deal chiefly with the instructor to obtain information (Al-Kandari, 2006). Comprehending ceases students' encountered knowledge from the instructor; learners then coordinate and save these concepts 
without substantive correction in the long-term memory and retrieve them once required. The instructor needs to break up and classify the knowledge given in a reasonable sequence to promote as well as strengthen learners' mechanical course of learning by heart and recall concepts easily.

It is good to know how teachers operate direct teaching method in classes.

The learners depend on teachers to decide the time of learning, the way of learning, and what to learn in the traditional direct teaching procedure. The instructor predominantly require that learners pay attention to the teacher's speech who would be following either a lecture system or an analytic methodology that mostly use Tag Questions or Detailed Questions that would require fundamental recollecting of information. Giving Instruction by mainly lecturing leads to control classroom exercises by the instructor who would be delivering more than $80 \%$ of the talk in most learning zones. (Zakaria \& Iksan, 2007). Mullis et al. (2004) stated that, in systematized knowledge learning zones, more than $20 \%$ of the time is spared on lectures, $19 \%$ on classwork, less than $15 \%$ on homework, and about $10 \%$ on problem solution done by students individually. This implies that, at traditional stages, learners argue and collaborate only upon the teacher's request and the collaboration is limited to a small amount of time plus it occurs only with their instructor in a question-andresponse interpretation format to get information instead of personal co-operative discussions and negotiations among the learners.

\section{DTM Influence on Attainment}

Direct teaching techniques may strengthen learner's work as Garrett (2008) suggested that learners enhance their advanced skills when instructional methods are centered around the teacher, including lectures, guided discussions, and demonstrations. However, in direct teaching classrooms in Kuwait, controlling plays a significant role, and the teacher wields control over the students (Al-Kandari, 2006). With these forms of instruction, the teacher tends to stand in the front of the classroom more like a skillful conductor, drawing the music out of the performers. The teacher is required to be a proficient operator, using questions and orders to elicit answers. Hence lessons are structured by teachers solely. Similarly, the physical design of the classroom is more like a presentation stage that often promotes a focus on the teacher and limits any student activity that disrupts this focus. In other words, rooms are often structured so that desks face the primary focal point. Therefore, the completion of a task is seen as a prerequisite for obtaining something desirable, and the method for gaining the knowledge is not as important as gaining the knowledge itself. Breaking the wholesome items into smaller ones, once thought to be the perfect and the only way to solve a problem. Here, in Kuwait educators following DTM think that comprehending only happens when learners sit separately thinking thoroughly.

\section{DTM Influence on Social Intelligence}

Incorporating communal intelligence isn't highlighted in traditional methods as most of the learning tasks depend on individual creation, which deemphasizes inter-personal efforts and cooperation. Going through traditional methods literature, the researchers didn't find a lot of studies that would recommend social intelligence.

\section{Criticisms of Direct Teaching Methods (DTM)}

There were many critical arguments about the direct teaching methods. First, students in such classrooms may find it difficult to adjust to life beyond school walls because they might not be accustomed to cooperation and socialization with others in actual world beyond home. They are not prepared for being successful in their life tasks because they may lack collaboration and communication. They may as well lack holding responsibility and respect towards others and towards the diverse world. In addition, learners under DTM might not have a chance to freely select the techniques which they like mostly to clear up tasks while in the contrary the instructors are free to choose a method of their own choice for the problem solutions.

However, followers of DTM may suffer from learners being tired of the one-way communication inherent in DTM so students should be equipped with classroom environments that utilize plenty of tasks, groupings, and settings (Saglam \& Arslan, 2018). Students are also inspired by instructors who dignify their personalities as free entity by offering them the chance to negotiate concepts or by allowing them to choose their own process.

\section{Current study: To study the influence of FLM compared to DTM on learners attainment and their use of social intelligence}

The current study analyzed the influence of flipped learning methods and direct teaching methods on the learners' attainment and their usage of social intelligence while learning. The study used the biology achievement post-test as the termination of the learning process. The scores earned in the biology attainment exams were measured and compared with the scores of the pre-test attainment.

Social intelligence is the quality of person's social functionality and his/her management to social situations as well as his/her personal social life (Jureviciene, Kaffemaniene, \& Ruskus, 2012). This type of education and skills will naturally promote learners to effectively communicate, meet the needs, relate with other students and interact with people in various 
Table 1. A Comparison of Flipped Learning and Direct Teaching Method

\begin{tabular}{ll}
\hline Flipped learning method & Direct Teaching method \\
\hline Information presented at home & Information presented in the classroom \\
Additional variable in class & Additional variable at home \\
Active learning strategies & Regular and lecture format strategies \\
Frees up valuable time in class & Requires more time for explaining \\
Positive and active student & Passive student \\
Views instructional videos and & Depends on lecture \\
Other media & Individual work is appreciated and \\
Increase teamwork skills and other teaching methods & Encouraged \\
\hline
\end{tabular}

occasions. This study highlighted the need for high school students to use social skills to obtain an attitude for teaming up and assisting each other. Also, it highlights individual accountability toward group mates and classmates, and having verbal conversation with classmates.

In the present investigation, FLM was structured techniques that offered learners chances to do things individually at home; to fix problems, search answers for questions, and do projects. They enabled students to support each other to enrich their own acquisition through a student-centered approach, thereby helping them actively learn knowledge from new lessons at their convenient time by utilizing smart phones or computer gadgets and iPads (Asiksoy \& Ozdamli, 2016). With these gadgets learning went beyond biology lessons into establishing main life intelligence, analytical reasoning, social beliefs and self-assurance. With online activities downloaded, they reinforced the important information in a fun and memorable way. Thus, learners acquire knowledge through such dynamic learning experiences.

The DTM in the present investigation as we discovered was primarily associated with the position of the teacher being the commander who had it all: knowledge and talents, and on whom the learners depended heavily (McDonald, 2002). In addition, students' grades from achievement tests were considered in the vanguard position seen nearly by many followers of direct teaching approaches, and from which teachers derived their liability standards and they were normally compelled to give up the learners' hopes and wishes of having extended discussion fearing not to finish the required curriculum.

As researchers we benefited a lot from Al-Rowais. AlRowais (2014), Wiginton, (2013), and Shi-Chun et al. (2014) compared flipped learning and direct teaching methods in the classroom (see Table 1). Their results provide insights into the differences between the methods. This comparison clearly indicates different goals for teaching: Direct teaching systems fix attention on content comprehension whereas flipped learning approaches focus on social development.

Learners' achievement and the usage of social intelligence in Al-Rowais study showed a remarkable outcome. We can benefit from this study and gradually develop our methods in schools of Kuwait, in case the future generation wants to be ready in terms of academic information and social relations to face and carry out their errands and their responsibilities in life.

Such modifications could only occur when teachers tend to use interesting and effective teaching routes to stimulate learners' learning and thinking.

Thus, before conducting this study the researchers examined several differences between flipped learning and direct teaching methods in terms of learners' scientific knowledge accomplishment and in terms of their social intelligence in high school biology learning zones. The investigation focused on addressing the following questions:

1- Is there any noticeable contradiction in $10^{\text {th }}$-grade learners' biology achievements when utilizing the two opposite kinds of guidance: flipped tutoring methods and direct teaching methods?

2 - Is there any noticeable contrast in $10^{\text {th }}$-grade learners' usage of social intelligence in biology classes when utilizing the two different kinds of directions: flipped learning methods and direct teaching methods?

What the present investigation conveys is that it tackles a significant issue in Kuwait: the need to improve biology achievement and enhance students' social intelligence. The investigation findings will give illustrations whether the educational systems can make good use of FLM to formulate new decisions about a pressing problem regarding the biology curriculum and instructions used in high school classrooms.

\section{Study Limitation}

This study is limited to tenth-grade learners who studied a unit that is about the cell division from tenth grade biology textbook of public schools, issued in 2018 and published by the Ministry of Education in Kuwait. The study was conducted in Jumana public school for girls in Abdullah Al Salem District, in Kuwait. The study was done in the second term of the academic year of 2018-2019. It is worth mentioning though that the study outcome was based on the responses given by the study participants to the valid and reliable instruments. 


\section{Study Methodology}

To answer the study questions, this quantitative study selected a pretest/post-test quasi- experimental pattern in order to analyze data and interpret results that the study would reveal. It included arbitrary tasks for two intact $10^{\text {th-grade }}$ classes that were under instructional assistance for enabling learners to analyze and answer the study questions. The independent variables in this study were the two instructional teaching methods (i.e., direct teaching and flipped learning methods). While the dependent variables were learners' biology attainment and their usage of their behavior intelligence. The language used for instructions as well as for the data collection of the test and the survey was Arabic.

\section{Study Participants}

The indicated school randomly specified two different classrooms in tenth grade in Jumana High School for Girls in Abdullah Al Salem District, Kuwait in the second term of the academic year of 2018-2019. The sample consisted of 37 female learners (19 experimental, 18 control). Typically, the average number of students in scientific classrooms in public schools in Kuwait is 22 to 25 learners. The experimental class were taught using flipped learning method and the control class followed traditional teaching methods. Their ages were between 15 years old to 16 years old.

\section{Study Instruments and Implementation Procedures}

To respond to the study questions and the main aims, the researchers chose the unit entitled cell division in the biology textbook of the tenth grade. The unit was evaluated, and diverse learning targets were identified. The instructors then refined the elements of the unit by laying out a flipped classroom model that included a mixture of tasks, handouts, PowerPoint, oral speeches, and some recorded videos clips related to their subject. The Kuwaiti Government Administration managers and teachers of science reviewed the refined elements of the unit to ensure that it was developmentally appropriate for $10^{\text {th }}$-grade students. The investigators asked the teacher to use the normal traditional direct teaching method with the control class and the flipped learning method with the experimental class. The teacher was taught how to follow these methods before the semester started. And the refined unit was implemented throughout the second semester of the 2018-2019 scholastic year.

An orientation was offered to the educator by the researchers. The teacher did not use flipped before, but she had a faith that she would be qualified enough to use FLM. Planning and having a debate on the best ways to use FLM for teaching the cell division unit were actually the major goals of the orientation. The alignment session incorporated debates on how instructors could inspire and encourage learners to ask further questions, demonstrate self-reliance throughout the learning procedure, and motivate students' involvement in vital scientific practices (e.g., observations, measurements, experimentations, interpretations of data, and guessing). This direction assisted the teacher to grasp the idea of FLM especially at the times when students were performing their tasks. It also benefited her in laying out her lessons plans and performing flipped learning materials that are tailored to the learner's own requirement using activities accessible by computer. The researchers asked the teacher to watch a video of a flipped learning setting that clarify learning procedures, and the Kuwaiti teacher found it extremely effective.

The trained instructors then presented the developed unit using a flipped classroom approach with the investigational group. The demonstration of each chapter of the unit was disciplined according to FLM style; to the training that he/ she completed at the beginning of the semester. The teacher met with learners twice a week. Every lesson plan carried on for 45 minutes. Prepared components papers were given out to students to revise in advance according to the next coming lesson plan. Students then went home and revised the materials assigned by the teacher. Consequently, learners could recall the materials as soon as the teacher started the lesson. They were asked about the subject of the lesson and the main idea of the material. A discussion unfolded afterwards between the teacher and students to further acknowledge their inquiries. The teacher also presented related practices, such as group work, experiments, and handouts to expand learners' acquaintance with the lesson.

The process of teaching lasted for 5 weeks to make sure that the groups had consistency and the same amount of time for directions. Initially, the researchers attended the biology classes to examine the students' attitude and the teacher's teaching methodologies in order to confirm the evasion of instructor prejudice and the compatible and consistent use of both prescribed methods. The researchers attended the classes until they were assured that the instructor was following the instructions and research techniques.

The control group was skilled using a traditional teaching strategy in which teaching concentrated on giving the components of the chapter by using the textbook as the major and only supply. The teacher presented each lesson in the lecture room and required from the learners to finish the homework task at home. In the DTM locations, students had to sit in rows especially while taking notes and looking up their assignments. When the exploratory groups met in the biology classroom, learners worked in an orderly manner. In FLM group there were five to six learners. All the learners were taught identical subjects from the academic unit as well as identical biology concepts. After five weeks of the implementation of the unit the two 
assigned groups responded to a post-test and a survey right after the unit ended. The participants carried out the experiment correctly.

\section{Data Collection Procedure}

The teacher prepared a test in order to assess students' biology achievement according to the identified learning objectives in both groups. 15 multiple-choice and open-ended questions were the elements of the test which was given as a pre-test and as a post test. The pre-test along with the survey of their social intelligence were handed out to both the experimental group and the control group at the very beginning of the second semester of the 2018-2019 academic year. The post-test was carried out after 5 weeks of teaching the unit (see Appendix A). The language of instruction of the test and the survey was Arabic. The learners' social intelligence was specified using a previous researcher-designed survey (Ebrahim, 2012) that was applied before in many of his different studies. In this study, it was administered as a preliminary survey and as post survey to measure the impact of both teaching methods on the utilization of their social intelligence at the chosen biology classrooms (see Appendix B). Then, the researchers examined the validity and reliability of both instruments.

\section{Validity and Reliability of the Instruments}

First the researchers would like to give a small definition to validity and reliability. Validity is defined as the extent to which a concept is accurately measured in a quantitative study. This refers to the appropriateness, meaningfulness and usefulness of the inferences a researcher makes. Reliability relates to the consistency of scores of participants completing an instrument questions and that would have approximately the same responses each time the test is completed (Heale \& Twycross, 2015, p. 67).

\section{Attainment Test and Social Intelligence Survey Validity}

The researchers presented the attainment test and the social intelligence survey to a panel of six professors to check the validity and reliability of the study instruments. Six expert professors from Kuwait University along with some biology teachers worked together to check the validity and reliability of both the test and the survey. These experts have experience in measurement, evaluation, teaching methods, and in biology curricula. The experts suggested few modifications to some items of the biology test, and the modifications were performed accordingly.

\section{Applying the Attainment Test and the Social Intelligence Survey to Exploratory Sample Validity}

Validity, as we mentioned earlier in our definition to validity, relates to whether the inferences the researchers make are appropriate, meaningful, and useful. Therefore, before carrying out to this investigation, the researchers carried out a pilot experiment to check the validity of our test and our social intelligence survey by distributing the two instruments to an exploratory sample that consisted of 12 learners from the tenth grade chosen randomly.

Some of the questions asked by the researchers:

1. Have you found the survey hard to solve?

2. Have you understood the given data of the test?

3. Have you found all the items of the survey and the test questions clear?

4. Which words or questions that have been vague to you?

All the learners turned in their answers saying that they had full comprehension of the questions and statements of the test and the survey.

\section{Reliability}

Reliability, as we mentioned earlier in our definition to reliability, relates to the consistency of a measure. Regardless of when a test is administered or who does the scoring, a test is only reliable when the same outcomes become consistent. (Heale \& Twycross, 2015). Therefore, before carrying on this investigation, the researchers carried out a pilot experiment to check the reliability of our test and our social intelligence survey by distributing the two instruments to an exploratory sample that consisted of 30 female learners in a $10^{\text {th }}$ grade biology class in Kuwait. These learners were not part of our study instructional groups, but rather outside the study sample and they were randomly chosen from $10^{\text {th }}$-grade classes.

The learners were chosen according to their completion of the targeted biology unit for this investigation. The biology attainment quiz and the social intelligence survey were conducted to the 30 learners. Basically, it's according to the learners' responses that the reliability of these instruments was probed using a Kuder-Richardson 20 procedure for determining subjective consistency. The outcomes for the attainment test declared adequate co-efficient of subjective consistency $(a=0.82)$. The search of the reliability of the social intelligence explained a satisfactory reliability coefficient of $(\mathrm{a}=0.76)$.

Consequently, both the attainment test and the social intelligence survey can be considered adequately valid and reliable instruments for measuring Kuwaiti students' biology attainment and usage of social intelligence in $10^{\text {th }}$-grade biology classes in this study. 
Table 2. Descriptive Statistics (sample sizes, means and standard deviations) of the FLM and DTM Groups' Biology Attainment

\begin{tabular}{lcccccc}
\hline \multirow{2}{*}{ Teaching Method } & \multicolumn{3}{c}{ Preliminary Test } & \multicolumn{3}{c}{ Post-Test } \\
\cline { 2 - 7 } & $\mathrm{N}$ & $\mathrm{M}$ & $\mathrm{SD}$ & $\mathrm{N}$ & $\mathrm{M}$ & SD \\
\hline DTM & 18 & 6.06 & 2.155 & 18 & 4.89 & 2.166 \\
FLM & 19 & 4.95 & 2.013 & 19 & 8.16 & 1.864 \\
\hline
\end{tabular}

Table 3. Result of the ANCOVA for the Difference between the Control and the Experimental Groups Posttest for Biology Attainment

\begin{tabular}{lcccccc}
\hline Source & Sum of square & Df & Mean square & F & P & Partial Eta squared \\
\hline Corrected Model & $98.777 a$ & 2 & 49.389 & 11.800 & .000 & .410 \\
Intercept & 187.478 & 1 & 187.478 & 44.793 & .000 & .568 \\
Pretest (covariate) & .000 & 1 & .000 & .000 & .992 & .000 \\
Teaching Method & 92.019 & 1 & 92.019 & 21.986 & .001 & .393 \\
Error & 142.304 & 34 & 4.185 & & & \\
Total & 1837.000 & 37 & & & \\
Corrected Total & 241.081 & 36 & & & \\
\hline
\end{tabular}

Note: ${ }^{\text {a }}$ R Squared $=.410$ (Adjusted R Squared $\left.=.375\right)$

Table 4. Detailed Statistics (sample sizes mean and standard deviations) of the FLM \& DTM group for Use of Social Intelligence

\begin{tabular}{lcccccc}
\hline \multirow{2}{*}{ Teaching method } & \multicolumn{3}{c}{ Preliminary test } & \multicolumn{3}{c}{ Post-test } \\
\cline { 2 - 7 } & $\mathrm{N}$ & $\mathrm{M}$ & $\mathrm{SD}$ & $\mathrm{N}$ & $\mathrm{M}$ & SD \\
\hline DTM & 18 & 8.44 & 1.464 & 18 & 2.72 & 8.081 \\
FLM & 19 & 9.79 & 1.686 & 19 & 8.89 & 1.853 \\
\hline
\end{tabular}

\section{Data Analysis}

The influence of both training methods (i.e., FLM, DTM) on learners' biology attainment and usage of social intelligence was explored in a separate one-way ANCOVA. Learners' scores on the attainment post-test and their responses to the social intelligence survey were used as the dependent variable. Training methods were used as the independent variable, and preliminary test scores were used as the covariant.

\section{Biology Achievement Results}

Primarily, all the learners chosen for the DTM group were nearly alike and comparable in number to the FLM group. The total number of the learners in both groups was 42 . Unfortunately, the researchers could not have all the required information for five learners in this investigation because five of the attainment and the survey test were missing for some reason. Consequently, data for only 37 learners were used in the final analyses. All learners were given a preliminary test and, after 5 weeks of the explicit guidance, a post-test was given to them. The descriptive statistics (sample sizes, means, and standard deviations) for the pretest and post-test results related to biology attainment are summarized in Table 2.

Table 2 shows that the preliminary test mean score of the DTM group was greater than that of the FLM group; nevertheless, the standard deviations were somewhat similar, and the post- test marks for the FLM group were greater than the mean score of the DTM group. Furthermore, the ANCOVA results indicated that the adjusted post- test mean score of the FLM group was significantly $(p=0.001)$ superior to that of the DTM group (Table 3 ).

Furthermore, Table 2 shows change at group DTM from 6.06 to 4.89 , and to explain this change we looked to Adjusted means, which showed this change is not statistically significant.

\section{Social Intelligence Outcomes}

The detailed statistics (sample sizes, means, and standard deviations) for the preliminary test plus the post- test results related to social intelligence are summarized in Table 4 . The social intelligence pretest mean mark of the DTM group was lower than that of the FLM group, and the social intelligence post-test mean mark of the FLM group was superior to that of the DTM group.

The ANCOVA is designed to correct unequal preliminary test outcomes. Consequently, the post-test test outcomes were adjusted using the preliminary scores as the covariant. The ANCOVA outcomes indicated that the FLM group's adjusted social intelligence post-test outcome was not significant $(p=$ 0.475; see Table 5).

\section{DISCUSSION AND CONCLUSION}

Benjamin Franklin once stated, "Tell me and I forgot, teach me and I may remember, involve me and I learn." Franklin's quote embodies the core of the flipped classroom concept. In this study when flipped method 
Table 5. Results of the ANCOVA for the Difference between the Control and the Experimental Groups Posttest for Use of Social Intelligence

\begin{tabular}{lcccccc}
\hline Source & Sum of squares & Df & Mean square & F & P & Partial Eta squared \\
\hline Corrected Model & 36.654 & 2 & 18.327 & 5.591 & .008 & .247 \\
Intercept & 12.855 & 1 & 12.855 & 3.922 & .056 & .103 \\
Preliminary test (covariate) & 23.946 & 1 & 23.946 & 7.305 & .011 & .177 \\
Teaching Method & 1.709 & 1 & 1.709 & .521 & .475 & .015 \\
Error & 111.454 & 34 & 3.278 & & & \\
Total & 2712.000 & 37 & & & & \\
\hline Corrected Total & 148.108 & 36 & & & \\
\hline
\end{tabular}

was properly implemented, environments became a positive experience for both teachers and biology learners who learned to value the increased engagement.

The correlative impact of FLM and DTM on learners' attainment showed that the flipped learning tactic has a more positive influence on students' achievement than the direct teaching method. This study result agreed with Al Rowais (2014) insights that learners who go under flipped learning method pointed out positive attainment. Also, the study result reinforces the results of Elian and Hamaidi (2018), who reported that there are detailed statistical variation in the mean on the educational attainment test attributed to the teaching strategy, in favor of the members of the experimental group. The vital outcome of their investigation showed that learners' performance in flipped training zone is superior to direct teaching environments. These findings might indicate that acquiring knowledge is highly interesting when students are exchanging ideas and joining each other in academic activities. Getting higher level of achievement is the main objective of flipped training methods-at least for female high school learners and biology students, as shown in the current study. Female students might play a more confident role in the tutoring procedures in the flipped zone than at direct teaching zone where the teacher plays the role of the director. When learners vigorously share in dynamic learning practices, they will be able to share ideas and comprehend tasks together. This situation is not available in a direct teaching classroom.

FLM puts special stress on learners and their learning techniques than on the instructors and their stages of presentations. By applying FLM, learners' intellectual abilities can become better as they develop their knowledge in scientific, practical, and behavioral areas. FLM appears to boost a feeling of having individual dependability and learners start to look at tasks as challenging, therefore it increases their motivation to learn. If students are enormously eager to learn, their level of attainment will get increased as well. In a flipped classroom, learners can connect what they learn with their intellectual attitudes until it becomes part of their personality (Dickenson, 2016).

Furthermore, researchers have proposed the optimistic influences of flipped training on students' acquisition of friendships and interpersonal relations (e.g., social interactions, commitment, confidence, love and motivation), thereby supporting active and social learning by providing venues for collaborating, constructing, and sharing information (Garrison \& Akyol, 2009; Noonoo, 2012). People usually like to get together, mainly women, who extremely appreciate being part of a group. To sum up, learning involvements reflect a great reverence to the learners' abilities, as they have many advantages upshots on their performance.

However, according to learners' use of social intelligence, the results revealed that FLM had no significant impact on communication skills. Thus, implementing a flipped learning method did not support learners' usage of social intelligence, in the biology learning zones at different levels. It was not more effective than the direct teaching method. This result is inconsistent with previous findings (Garrison \& Akyol 2009; Noonoo, 2012; Strohmyer, 2016). The researchers assumed that the reason behind this is that the learners were used for a long time to the idea that the major source of knowledge in a classroom was usually the teacher so students were used to dealing primarily with the teacher more than communicating with each other to search for information. For many years, they were used to learning by having a passive reception of knowledge given by the instructor. The successive organization and storage of this concept of being a passive listener remained the same in their long-term memory without actual alteration. Moreover, an interview with the teacher revealed the second reason from her point of view for why flipped learning methods didn't influence their social intelligence. She thought that some students who did not have technological devices found it hard to benefit from this method. Furthermore, it happened that their parents took their gadgets from them in order not to get busy with them while preparing themselves for school tests. Unfortunately, this happened during the same time when this investigation took place. This incident led them to ask the teacher to watch the recorded materials in class. Consequently, for future investigations on flipped training methods, researchers should acknowledge the parents about the experiment and warn them not to take the gadgets from the learners, then probably we will be noticing the positive effect of flipped learning on students' social intelligence. It is most 
importantly as well not to forget tackling its minor limitations before conducting new FLM experiments.

Nevertheless, the outcomes of this investigation have many implications for teachers in Kuwaiti schools using biology-related teaching methods. The value of utilizing FLM rather than DTM is highlighted in this investigation especially when having biology lectures, that's because of its good effects on learners' attainment. Clearly, the former results support flipped learning procedures in Kuwait. It is very important that the Government administrators notice this paper and support the use of flipped learning methods and apply these practices in their schools. In addition, more studies are wanted to test the influence of FLM on learners' attainment and their usage of social intelligence.

\section{STUDY RECOMMENDATION}

The study suggested that more studies should be done on different gender and on diverse educational levels, with various biology articles, and different materials and areas. And for future research we suggest considering having larger sample sizes in order to get higher effect size. The researchers also suggest providing schools with sufficient technological gadgets, laboratory equipped with the latest devices, and fast internet to help educators plan the required subject matter following the flipped learning style. Finally, the study findings encourage the trainee instructors at the College of Education at Kuwait University to receive sufficient guidance on using new teaching methods in particular flipped classroom methods to improve the academic attainment of students as well as their social intelligence.

Author contributions: All authors have sufficiently contributed to the study, and agreed with the results and conclusions.

Funding: No funding source is reported for this study.

Declaration of interest: No conflict of interest is declared by authors.

\section{REFERENCES}

Al-Kandari, A. (2006). To what extent science education objectives are presented in science teachers' lesson plans in Kuwait schools. The Educational Journal, 20(80).

Almodaires, A., Alayyar, G., Almsaud, T., \& Almutairi, F. (2018). The Effectiveness of Flipped Learning: A Quasi-Experimental Study of the Perceptions of Kuwaiti Pre-Service Teachers. Canadian Center of Science and Education, 12(1), 10-23. https:/ / doi.org/ 10.5539/ies.v12n1p10

Almutairi, F., Almodaires, A., \& Zeyab, A. (2020). Effectiveness of Flipped Learning: Improving PreService Teachers' Prowess in Producing Videos. International Education Studies, 13(7), 163-176. https://doi.org/10.5539/ies.v13n7p163
Al-Rowais, A. (2014). The impact of flipped learning on achievement and attitudes in higher education. International Journal for Cross-Disciplinary Subjects in Education, 4(1), 1914-1921. https://doi.org/ 10.20533/ijcdse.2042.6364.2014.0266

Alzain, H. (2015). The impact of the application of the concept of the inverted row in the academic achievement of students in the Faculty of Education Princess Nora bint Abdul Rahman University. The International Journal of Educational Specialist, 4(1), 171-186.

Asiksoy, G., \& Ozdamli, F. (2016). Flipped classroom adapted to the ARCS model motivation and applied to a physics course. Eurasia Journal of Mathematics, Science \& Technology Education, 12(6), 1589-1603. https:/ / doi.org/10.12973/eurasia.2016.1251a

Bergmann, J., \& Sams, A. (2012). Flip your classroom: Reach every student in every class every day. International Society for Technology in Education.

Bishop, J. L., \& Verleger, M. A. (2013). The flipped classroom: A survey of the research. ASEE National Conference Proceedings, 30(9), 1-18. https:/ / doi.org/ 10.18260/1-2--22585

Buechler, D. N., Sealy, P. J., \& Goomey, J. (2014). Three pilot studies with a focus on asynchronous distance education [Paper presentation]. Proceedings of 121st ASEE annual conference \& exposition, Indianapolis, IN.

Cavalli, M., Neubert, J. J., Mcnally, D., \& JacklitchKuikan, D. (2014). Comparison of student performance and perceptions across multiple course delivery modes [Paper presentation]. Proceedings of 121st ASEE annual conference, Indianapolis, IN.

Cheng, L., Ritzhaupt, A. D., \& Antonenko, P. (2018). Effects of the flipped classroom instructional strategy on students' learning outcomes: A meta-analysis. Educational Technology Research and Development, 67, 793-824 https://doi.org/10.1007/ s11423-018-9633-7

DeLozier, S. J., \& Rhodes, M. G. (2017). Flipped classrooms: A review of key ideas and recommendations for practice. Educational Psychology Review, 29(1), 141-151. https:/ / doi.org/ 10.1007/s10648-015-9356-9

Dickenson, P. (2016). The flipped classroom in a hybrid teacher course: Teachers' self-efficacy and instructors' practices. Journal of Research in Innovative Teaching, 9(1), 78-89.

DiPrete, T. A., \& Jennings, J. L. (2012). Social and behavioral skills and the gender gap in early educational achievement. Social Science Research, 41(1), 1-15. https://doi.org/10.1016/j.ssresearch. 2011.09.001 
Ebrahim, A. (2012) The effect of cooperative learning strategies on elementary students' science achievement and social skills in Kuwait. International Journal of Science and Mathematics Education, 10(2), 293-314. https:/ / doi.org/10.1007/ s10763-011-9293-0

Elian, S. A., \& Hamaidi, D. A. (2018). The effect of using flipped classroom strategy on the academic achievement of fourth grade students in Jordan. International Journal of Emerging Technologies in Learning, 13(2), 110-125. https://doi.org/10.3991/ ijet.v13i02.7816

Esperanza, P., Fabian, K., \& Toto, C. (2016, September). Flipped classroom model: effects on performance, attitudes and perceptions in high school algebra. European Conference on Technology Enhanced Learning, 85-97. https://doi.org/10.1007/978-3319-45153-4_7

Garrett, T. (2008). Student-centered and teacher-centered classroom management: A case study of three elementary teachers. Journal of Classroom Interaction, 43(1), 34-47.

Garrison, D. R., \& Akoyl, Z. (2009). Role instructional technology in the transformation of higher education. Journal of Computing in Higher Education, 21(1), 19-30. https://doi.org/10.1007/s12528-0099014-7

Garrison, D. R., \& Vaughan, N. D. (2008). Blended learning in higher education: Framework, principles, and guidelines. Jossey-Bass. https://doi.org/10.1002/ 9781118269558

Heale, R., \& Twycross, A. (2015). Validity and reliability in quantitative studies. Evidence-based Nursing, 18(3), 66-67. https://doi.org/10.1136/eb-2015102129

Jureviciene, M., Kaffemaniene, I., \& Ruskus, J. (2012). Concept and Structural Components of Social Skills. Baltic Journal of Sport and Health Sciences, 3(86), 42-52. https:/ / doi.org/10.33607/ bjshs.v3i86. 266

Kadioglu, C., Uzuntiryaki, E., \& Capa, A. Y. (2011). Development of self-regulatory strategies scale (SRSS). Education and Science, 36(160), 11-23.

Kiat, P. N., \& Kwot, Y. T. (2014). The flipped classroom experience. In Proceedings of IEEE CSEEET (pp. 3943). IEEE Xplore Digital Library. https:/ / doi.org/10.1109/CSEET.2014.6816779

Lavelle, J. P., Stimpson, M. T., \& Brill, E. D. (2013). Flipped out engineering economy: Converting a traditional class to an inverted model. In A. Krishnamurthy \& W. K. V. Chan (Eds.), Proceedings of the 2013 industrial systems engineering research conference (pp. 397-407). High Beam Research.
Li, B., Zheng, W., \& Yang, F. (2017). Cooperation learning of flip teaching style on the MBA mathematics education efficiency. EURASIA Journal of Mathematics Science and Technology Education, 13(10), 6963-6972. https://doi.org/ 10.12973 / ejmste/76878

Martin, M. O., Mullis, I. V. S., Foy, P., \& Hooper, M. (2016). TIMSS 2015 international results in science. Boston College, TIMSS, \& PIRLS International Study Center. http://timssandpirls.bc.edu/timss 2015/international-results /

McDonald, J. P. (2002). Teachers studying student work: Why and how? Phi Delta Kappan, 84(2), 120-127. https: / / doi.org/10.1177/003172170208400207

Michelson, L., Sugai, D., Wood, R., \& Kazdin, A. (1983). Social skills assessment and training with children: An empirically based handbook. Plenum. https:/ / doi.org /10.1007/978-1-4899-0348-8

Millard, E. (2012). 5 reasons flipped classrooms work: Turning lectures into homework to boost student engagement and increase technology-fueled creativity. http:/ / www.universitybusiness.com/article/5reasons-flipped-classrooms-work

Mok, H. N. (2014). Teaching tip: The flipped classroom. Journal of Information Systems Education, 25(1), 7-11.

Mullis, I. V., Martin, M. O., Gonzalez, E. J., \& Chrostowski, S. J. (2004). TIMSS 2003 international mathematics report: Findings from IEA's Trends in International Mathematics and Science Study at the fourth and eighth grades. TIMSS \& PIRLS International Study Center.

Noonoo, S. (2012, June 20). Flipped learning founders set the record straight. THE Journal. http:/ / thejournal.com/articles/2012/06/20/flipp ed-learning-founders-q-and-a.aspx

Pashler, H., McDaniel, M., Rohrer, D., \& Bjork, R. (2008). Learning styles: Concepts and evidence. Psychological science in the public interest, 9(3), 105119. https://doi.org/10.1111/j.1539-6053.2009.010 38.x

Rotellar, C., \& Cain, J. (2016). Research, perspectives, and recommendations on implementing the flipped classroom. American Journal of Pharmaceutical Education, 80(2), 34. https://doi.org/10.5688/ ajpe80234

Saglam, D., \& Arslan, A. (2018). The effect of flipped classroom on the academic achievement and attitude of higher education students. World Journal of Education, 8(4), 170-176. https://doi.org/ 10.5430/wje.v8n4p170

Sargent, J., \& Casey, A. (2019). Flipped learning, pedagogy and digital technology: Establishing consistent practice to optimize lesson time. European Physical Education Review, 26(1), 70-84. https:/ / doi.org/10.1177/1356336X19826603 
Shi-Chun, D., Ze-Tian, F., \& Yi, W. (2014, April). The flipped classroom-Advantages and challenges. International Conference on Economic Management and Trade Cooperation (EMTC 2014), 17-20. https:/ / doi.org/10.2991/emtc-14.2014.3

Sletten, S. R. (2017). Investigating flipped learning: Student self-regulated learning, perceptions, and achievement in an introductory biology course. Journal of Science Education and Technology, 26(3), 347-358. https:/ / doi.org/10.1007/s10956-016-96838

Strayer, J. F. (2012). How learning in an inverted classroom influences cooperation, innovation and task orientation. Learning Environments Research, 15(2), 171-193. https://doi.org/10.1007/s10984012-9108-4

Strohmyer, D. (2016). Student perceptions of flipped learning in a high school math classroom (Doctoral dissertation), Walden University. http:/ / scholarworks.waldenu.edu/cgi/viewconte nt.cgi? article $=3281 \&$ context $=$ dissertations

Tomas, L., Evans, S., Doyale, T., \& Skamp, K. (2019). Are first year students ready for a flipped classroom? A case for a flipped learning continuum. International Journal of Educational Technology in Higher Education, 16(1), 5. https:/ / doi.org/10.1186/s41239-019-01354
Tully, D. (2014). The effects of a flipped learning model utilizing varied technology versus the traditional learning mode in high school biology classroom (MA thesis), Montana State University. http:/ / scholarworks.montana.edu/xmlui/bitstrea m/handle/1/3600/TullyD0814.pdf;sequence=1

Velegol, S. B., Zappe, S. E., \& Mahoney, E. (2015). The evolution of a flipped classroom: Evidence-based recommendations. Advances in Engineering Education, 4, 1-37.

Wasserman, N. H., Quint, C., Norris, S. A., \& Carr, T. (2017). Exploring flipped classroom instruction in calculus III. International Journal of Science and Mathematics Education, 15(3), 545-568. https:/ / doi.org/10.1007/s10763-015-9704-8

Wiginton, B. (2013). Flipped instruction: An investigation into the effect of learning environment on student selfefficacy, learning style, and academic achievement in an algebra I classroom (Doctoral dissertation), University of Alabama.

Zakaria, E., \& Iksan, Z. (2007). Promoting cooperative learning in science and mathematics education: A Malaysian perspective. Eurasia Journal of Mathematics, Science \& Technology Education, 3(1), 35-39. https:// doi.org/10.12973/ejmste/75372 


\section{APPENDIX A}

Ministry of Education Student name:

Al-Asema Educational Area Grade: 10 / .....

Biology test

\section{Achievement Test}

\section{Part 1: Choose the correct answer from the following:}

1. Some of these actions occur during the primary growth stage of the interphase:

$\square$ Chromatin fibres replication $\square$ Organelle synthesis

$\square$ Hypertrophy $\square$ Centriole division

2. The period between the start of cell division and the beginning of the mitosis process is called:

$\square$ Interphase $\square$ Cell cycle $\square$ Prophase $\square$ Anaphase

3. The stage of meiosis that includes chromosomes' split is called:

$\square$ Prophase I $\square$ Metaphase I $\square$ Anaphase II $\square$ Anaphase I

4. Which one of the following syndromes is caused by a missing chromosome:

$\square$ Turner syndrome $\square$ Down syndrome

$\square$ Klinefelter syndrome $\square$ Cri-du-chat syndrome

5. Which one of the following is a result of the meiosis process:

$\square 1$ cell with 1 nucleus $\square 2$ cells with 2 nuclei

$\square 4$ cells with 1 nucleus $\square 8$ cells with 1 nucleus

Part 2: Compare the two lists and match items in A with the appropriate picture in B:

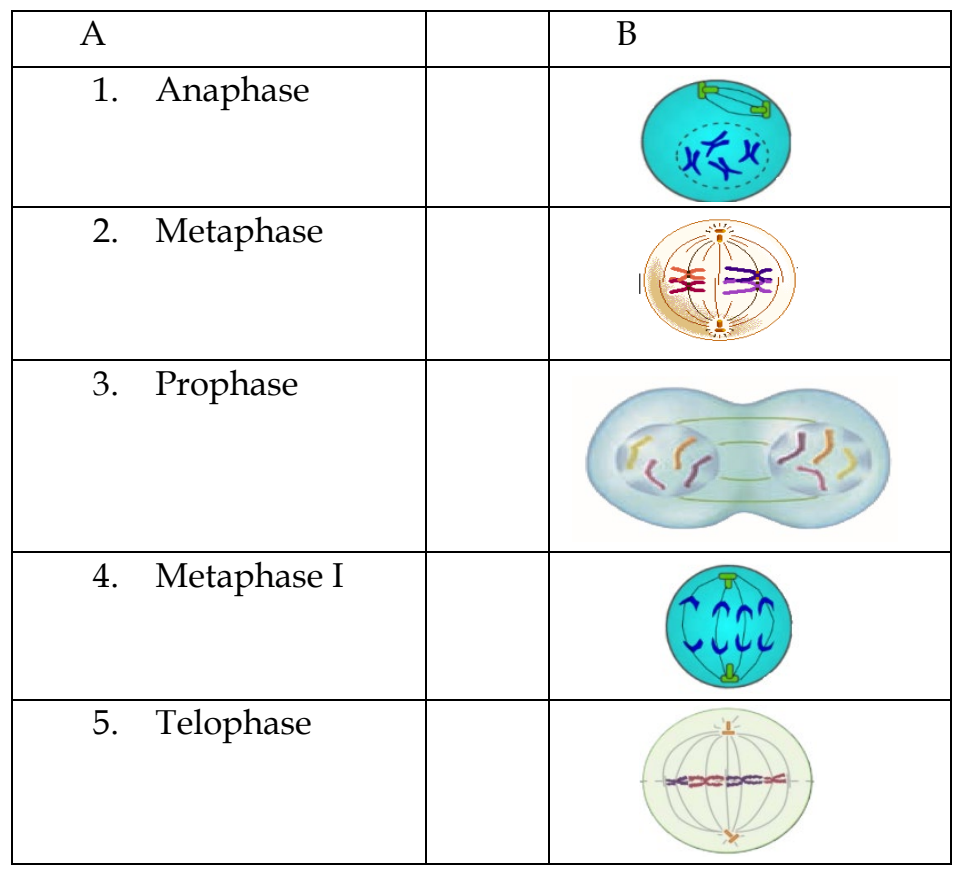

\section{Part 3: Mark $(\checkmark)$ or $(X)$ next to the following sentences:}

1. Cells divide in living organisms to grow, proliferate, and replace damaged tissues. ()

2. Cytokinesis occurs in a plant's cells during the telophase. ()

3. The difference between mitosis and meiosis is that mitosis produces cells with one identical nucleus. ()

4. Chromosomal translocation and exchange of parts between homologous chromosomes is called synapsis. ()

5. During the process of mitosis in the prophase, the nuclear material appears as a chromatin network. () 


\section{APPENDIX B}

\section{Social Intelligence Survey}

The data collected in this survey will not be published or provided except in a minimalized, short brief form with a view to maintaining the confidentiality of the data. Try to recall your biology classes from the past few weeks. First, read the following yes/no statements silently. Next, listen carefully to the teacher as she reads the items. Using the scale provided, choose either yes or no to answer based on the statement's validity by blackening the face that shows your choice.

\begin{tabular}{|c|c|c|}
\hline & Yes & No \\
\hline I have been able to assist my friends who asked for help during the biology class. & (:) & $\because ;$ \\
\hline I have been able to work together with my colleagues while answering questions or solving problems. & ;) & :) \\
\hline I have learned how to freely select the best choice to solve a problem. & ;) & :) \\
\hline In the biology class, I have been able to discuss biology materials with m class-mates. & (:) & :) \\
\hline In the biology class, I have often cared about my colleagues' comprehension. & ;) & (2) \\
\hline I have learned how to make friendships in the biology class. & ;) & :) \\
\hline $\begin{array}{l}\text { I have learned how to work in groups and pairs to find solutions for problems or answer questions in } \\
\text { the biology class. }\end{array}$ & ;) & :) \\
\hline I have not liked at all working in groups because my group mates have been falling behind. & :) & :) \\
\hline I have not liked working in groups because my group mates have been intolerant with me. & ;) & :) \\
\hline $\begin{array}{l}\text { I have not liked working in groups because my colleagues in the group have been busy playing while I } \\
\text { have been working to answer the questions. }\end{array}$ & ;) & (2) \\
\hline $\begin{array}{l}\text { I have not liked working in groups because it consumes a lot of my time and effort to teach my friends } \\
\text { the correct answers. }\end{array}$ & (:) & :) \\
\hline $\begin{array}{l}\text { I have not liked working in groups because my group mates would not hear me having another way of } \\
\text { solution. }\end{array}$ & :) & :) \\
\hline
\end{tabular}

\section{http://www.ejmste.com}

